\title{
Singing for your supper: Staff singing for transformation and teambuilding in a South African bank
}

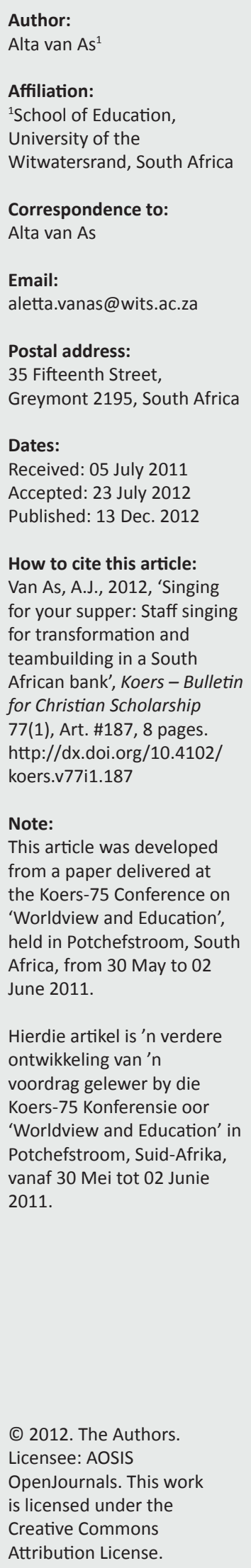

Author:

Affiliation:

University of the

Correspondence to:

Alta van As

Email:

Postal address:

35 Fifteenth Street,

Dates:

How to cite this article:

Van As, A.J, 2012, 'Singing

for transformation and

teambuilding in a South

for Christian Scholarship

77(1), Art. \#187, 8 pages.

http://dx.doi.org/10.4102/

Note: Conference on 'Worldview and Education', held in Potchefstroom, South Africa, from 30 May to 02

ontwikkeling van 'n

voordrag gelewer by die Koers-75 Konferensie oor 'Worldview and Education' in Potchefstroom, Suid-Afrik vanaf 30 Mei tot 02 Junie 2011.
Transformation entails meaningful change. In South Africa (as is increasingly the case in Europe and elsewhere), such change hinges on interaction and communication between citizens of different cultures, ethnicities and languages. Where the inability to speak the others' language(s) can inhibit real interaction and genuine communication, choral singing proffers unique opportunities for shared communicative experiences. In 2005, Dr Steve Booysen, then Group Chief Executive of the Absa Group, initiated an internal choir festival as a platform for social interaction and teambuilding for staff across all cultures, age groups and post levels in the bank. Booysen envisaged the choir project as a means of moral support during the AbsaBarclays merger. This article reports on the results of a Doctoral investigation into the extramusical benefits of this project for Absa, such as transformation and teambuilding. Choral singing as social capital is discussed. The Absa choir project can serve as a microcosm of larger multicultural, multilingual macrocosms. The benefits attained through communal singing in this project may also hold possibilities for attaining unity in diversity in South Africa.

Sing vir jou aandete: Personeel sing vir transformasie en spanbou in 'n Suid-Afrikaanse bank. Transformasie behels betekenisvolle verandering. In Suid-Afrika (soos toenemend ook die geval is in Europa en elders) is sodanige verandering afhanklik van die interaksie en kommunikasie tussen landgenote van verskillende kulture, tale en rasse. Terwyl die onvermoë om mekaar se tale te praat ware interaksie en kommunikasie kan inhibeer, bied koorsang unieke geleenthede vir gesamentlike kommunikasie-ervarings. Dr Steve Booysen, destyds Groep Uitvoerende Hoof van die Absagroep, het in 2005 'n interne koorfees ingestel om te dien as platform vir sosiale interaksie en spanbou vir personeel van alle kultuurgroepe, ouderdomme en posvlakke in die bankgroep. Booysen se visie was dat hierdie koorprojek sou dien as 'n middel tot morele ondersteuning gedurende die Absa-Barclays-samesmelting. Hierdie artikel fokus op die resultate van 'n doktorale studie wat die nie-musikale voordele van koorsang, soos transformasie en spanbou, ondersoek. Die Absa-koorprojek kan gesien word as 'n mikrokosmos van 'n groter, multikulturele, veeltalige makrokosmos. Die voordele wat die samesang in die koorprojek teweeg gebring het, mag belofte inhou vir die bou van eenheid in diversiteit in Suid-Afrika.

\section{Introduction}

The term 'transformation' has been used excessively in most spheres of South African public life. Reddy (2008) notes that the words 'revolutionary', 'reformist', 'broad-based', 'elitist', 'grassroots', 'human-rights-driven', 'participatory', 'just' and 'de-racialise' are amongst the keywords in the language of post-apartheid politics, but that 'transformation' 'top[s] the list'. Notwithstanding the prominence this term has enjoyed in the seventeen years of democracy, South Africans still have a long way to go to transform into a truly united nation. In the 2011 Parliamentary speech to launch the Diagnostic Report of the National Planning Commission, Minister Trevor Manual pronounced that 'we remain a divided society', and that the major dividing line in society is still race. Mkhize (2007:1) notes that it is possible that, in this country, 'in interpersonal and even intergroup encounters, an unconscious racialised process kicks in'. Any endeavour to transform South African society simply in terms of equity, without addressing these racialised perceptions, will fall short of the meaning of the term; a process of change affecting mindset, behaviour and culture (Anderson \& Ackerman Anderson 2010:2).

The project to establish a corporate choir presented a serendipitous opportunity to engage in the challenge of transforming some of the racialised perceptions mentioned above.

Dr Steve Booysen, then Group Executive Officer of Absa (at the time the biggest banking corporation in South Africa), initiated the Absa Internal Choir Competition in 2005. Booysen saw the choir project as an opportunity for Absa employees across the full range of cultural, 
ethnic and language diversity to participate collectively in a stress-releasing, bonding enterprise. Soon employees were saying that, above and beyond enjoying the singing and new friendships formed in the Absa choirs, the experience was impacting the way they perceived and related to colleagues of different races and cultures. These reports motivated the present article, which is based on a doctoral investigation into the efficacy of choral singing as tool for transformation and teambuilding in the corporate environment of Absa Bank.

This article reports on the findings of the investigation, and aims to establish an argument for incorporating choral singing as an agent for achieving meaningful change in South African business and civil communities. The author's views on how choral singing and the perceived value of the Absa Internal Choir Competition relate to a Christian worldview are integrated into the text.

\section{Research method}

The investigation of the Absa Internal Choir Competition (hereafter AICC) was both a quantitative and qualitative research project. Questionnaires were used as the main instrument for data collection. As it was situated in Absa Bank, the investigation needed to be informed by the vision of the company's human resource department. Absa identified six factors for this purpose.

A range of six to eight questions were designed to query different facets of each factor; these were then collected in a questionnaire.

This study investigated each factor in terms of individual profiles which included gender, age, race, language, province and position in the bank. The factors were also investigated in terms of group profiles: individual profiles were grouped in terms of gender, age, language, et cetera, to establish commonalities and differences in perceptions of each of these factors. Summative quantitative data on factors related to the focus of this article, namely transformation, teambuilding and improved cross-departmental collaboration, (factor 3, factor 4 and factor 5) are presented. Results of the survey relating to fun, increased pride in the Absa brand and enhanced belief

TABLE 1: Factors investigated.

\begin{tabular}{ll}
\hline Factors & Key questions \\
\hline 1. Fun & $\begin{array}{l}\text { How did participants assess the enjoyment } \\
\text { value of the AICC? }\end{array}$ \\
3. Cultural diversity & $\begin{array}{l}\text { To what extent has this project instilled an } \\
\text { increased sense of corporate pride? }\end{array}$ \\
& $\begin{array}{l}\text { How do respondents perceive the effect of } \\
\text { choir participation in the way they view and } \\
\text { interact with choir members of different } \\
\text { races and cultural backgrounds? }\end{array}$ \\
4. Teambuilding & $\begin{array}{l}\text { To what extent has the AlcC facilitated an } \\
\text { increased sense of belonging, trust, and } \\
\text { cooperation between choir members of } \\
\text { different races and cultural backgrounds? }\end{array}$ \\
5. Improved cross-departmental & $\begin{array}{l}\text { To what extent have the friendships and } \\
\text { trust developed in the choirs had a positive } \\
\text { effect on cross-departmental transactions in } \\
\text { the bank? }\end{array}$ \\
6. Staff as the 'most important asset' & $\begin{array}{l}\text { To what extent has this project instilled in } \\
\text { employees a sense of being valued as an } \\
\text { important individual? }\end{array}$ \\
\hline
\end{tabular}

that Absa employees are valued as individuals (factor 1, factor 2 and factor 6) will be discussed in the conclusion.

Qualitative data were obtained through open-ended questions in the questionnaire and analysed in terms of the themes that emerged from these comments. Some comments from respondents on themes relating to the content of the article, are also included.

The sample represented the demography of the organisation: male and female AICC participants from all provinces, age groups, races (ethnic groups), language groups and post levels in the bank. The outcomes of the questionnaires reflect the perceptions of 755 respondents across three interventions, labelled Intervention 1 (I1), Intervention 2 (I2) and Intervention 3 (I3). I1 and I2 took place in 2006. In the light of the overwhelming positive results of I1 and I2, the written questionnaires as well as the interviews were administered for a third time (I3) in 2008. This was intended to ascertain the sustainability of the choir project over time.

The multi-disciplinary nature of this study necessitated the consideration of a spectrum of fields that are not normally associated with traditional music education research. This article briefly reflects on notions of teambuilding, social capital and transformation as it relates to the Absa choir process.

\section{The Absa Internal Choir Competition}

Booysen initiated the first AICC in the wake of the Barclays investment of billions of rands that would translate to the British bank obtaining a controlling share in Absa. Empathy with Absa staff was a motivating factor for launching the AICC. Recognising the Absa-Barclays merger as a potential threat to the morale of the Absa workforce, Booysen envisaged the choir project as a catalyst for team and morale building for Absa employees during this phase of transition in the bank. In a DVD recorded in 2005 and supplied to the author in 2008 (see Van As 2009), Booysen also expressed the hope that singing in Absa choirs 'will bring about a greater sense of spiritual and emotional balance in the lives of our employees' (pers. comm., 04 July 2007). On the topic of mergers and acquisitions, Claire Gordon-Brown (2005) points out:

It is the people issues, more than the process issues. Processes themselves don't have emotions that have to be dealt with. People do, and this is what makes them more complicated ... it is about people at the end of the day ... and often companies do not understand their feelings, fears and aspirations. (p. 47)

Booysen saw the choir project as an opportunity for Absa employees to participate collectively in a stress-releasing, bonding pursuit. The AICC further presented a channel for embracing the 'bigger Absa family' and the Absa brand on a personal level in the midst of the Absa-Barclays merger. Ashkenas and Francis (2000:108-116) note that a successful integration manager is someone who is emotionally and culturally intelligent, understands that mergers and acquisitions affect people's lives and has the ability to bridge gaps in culture and perception. One could argue that by the initiating this project Booysen distinguished himself as such a manager. 
Absa choirs were formed at the beginning of the year by employees of one or more branches, business units, towns or regions. Every choir then prepared for the AICC semifinals, where the best choir in the province was selected to represent their province at the national AICC. The competition comprised two categories:

\section{Prescribed Absa song}

\section{Own choice item.}

The researcher was introduced to the project when commissioned to compose the first Absa song for the competition $^{1}$. Commenting on the value of singing in a corporate context, Welch (2005:254) notes that the use of 'specially composed company songs' can be a particularly positive instrument for reinforcing senior management's understanding of company culture. In keeping with the Absa slogan 'Today, tomorrow, together', the prescribed Absa songs endeavoured to highlight values and attitudes of purpose, respect, goodwill, hope, joy and togetherness in diversity. Welch (2005:254) further observes that, in choirs where significant diversity occurs, singing can become a 'transformational activity culturally' through the fusion of elements presented in the music traditions of the diverse cultures within the choir. This became particularly evident in the AICC own choice items. Choirs demonstrated great ingenuity in weaving together material (folk and/or popular songs) from all cultural groups represented in their choir into entertaining and often moving choral medleys, all within the prescribed time limit of three minutes. In both categories choirs were assessed on the quality of their singing as well as the enjoyment value of the performance for both choir and audience.

\section{The Absa Internal Choir Competition profile}

The AICC is a project that exemplifies inclusivity in the workplace. As the choirs were open to all employees in the bank (particularly encouraging the participation of differently abled staff), diversity was a typical trait of each one. The following bar graphs (Figure 1 - Figure 5) illustrate the overall profile of the AICC in terms of gender, ethnicity, age, language and post level in the bank.

It is interesting to note the increase in male participation from I1 to I3. However, the majority of the 2006 and 2008 AICC participants were female. Consequently the majority of the data represent women's views.

AICC participation by Black employees increased notably from the first intervention, I1, in 2006 to the third intervention, I3, in 2008. The ethnic profile of the AICC illustrates how this choir project created opportunities for developing and nurturing friendships with members of other races. Interestingly, it also reflects the status of choral singing in South African cultural groups. Whilst choral singing is not a customary practice of Indian communities in this country (Van As 2009:69), it is a particularly important feature of 'the black South African way of life' (Smith 1996).

1.The author subsequently composed three more Absa songs for the Absa Interna Choir Competition (2006-2008)

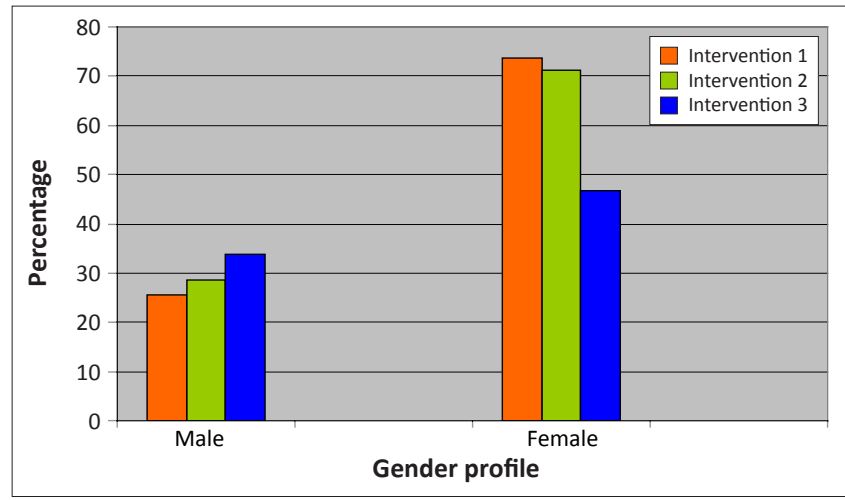

FIGURE 1: The Absa Internal Choir Competition gender profile.

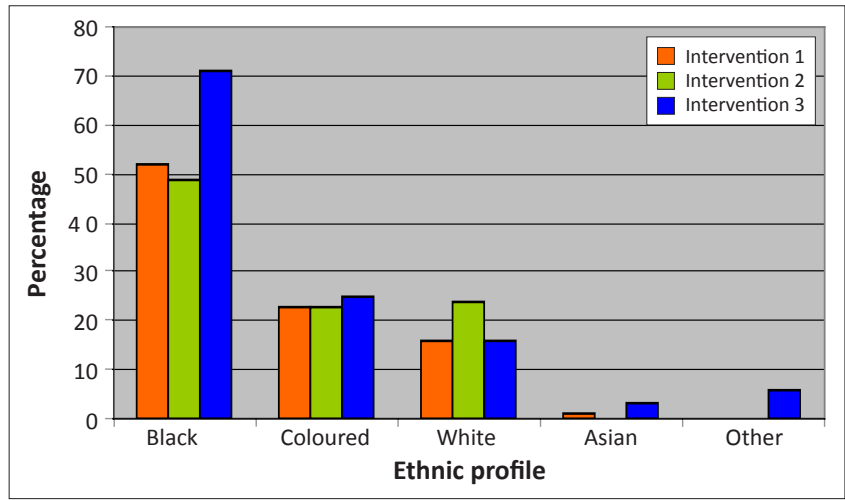

FIGURE 2: The Absa Internal Choir Competition ethnic profile.

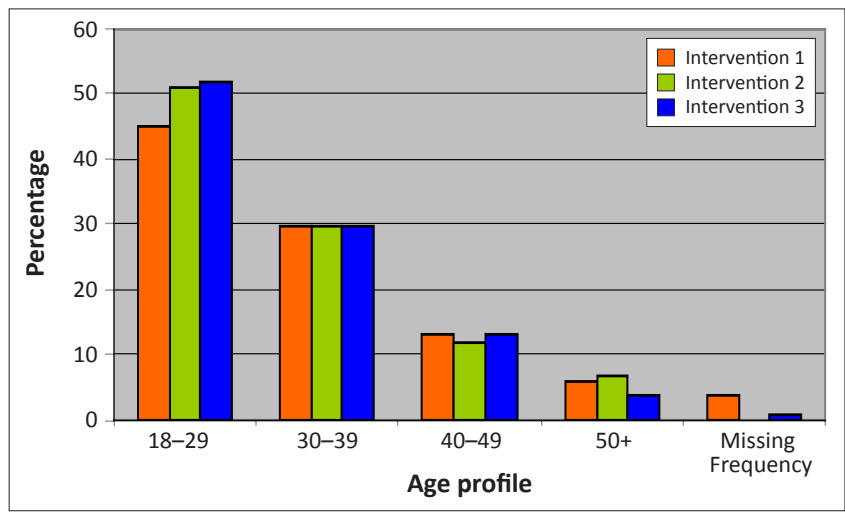

FIGURE 3: The Absa Internal Choir Competition age profile.

A recent study into the generic music style preferences of urban South African adolescents living in Johannesburg revealed that students from all socio-economic strata more often than not indicated a preference for Western choral music; moreover, more students indicated a preference for Western choral music rather than rock music (Matthews 2011:160). Figure 3 shows that Absa employees between the ages of 18 and 29 found participating in choral singing appealing.

All South African languages are represented in the AICC. AICC participants who indicated that they could speak an African language (excluding Afrikaans) as well as English and/or Afrikaans were overwhelmingly Black. This mirrors the situation in South African society: it is more likely for Black participants to be able to speak Afrikaans and/or English and it is probable that only a few White South Africans can speak an African language (excluding Afrikaans). 


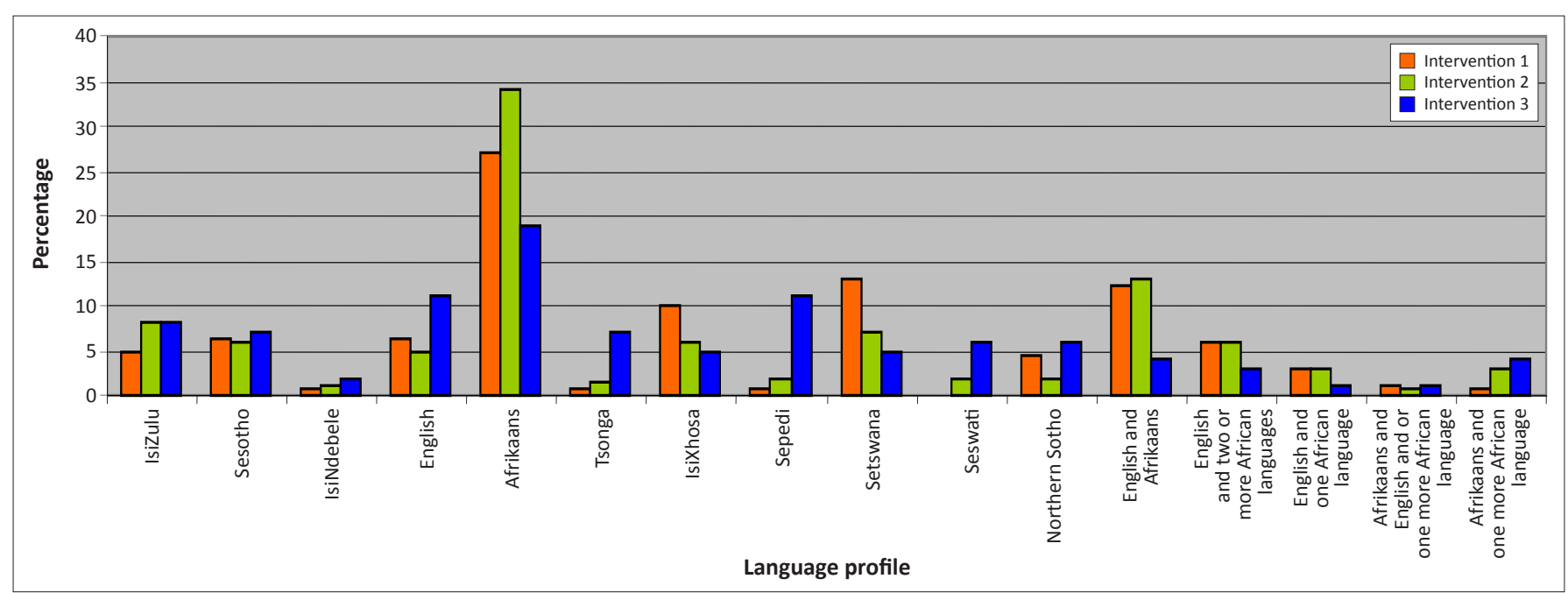

FIGURE 4: Languages spoken by Absa Internal Choir Competition participants.

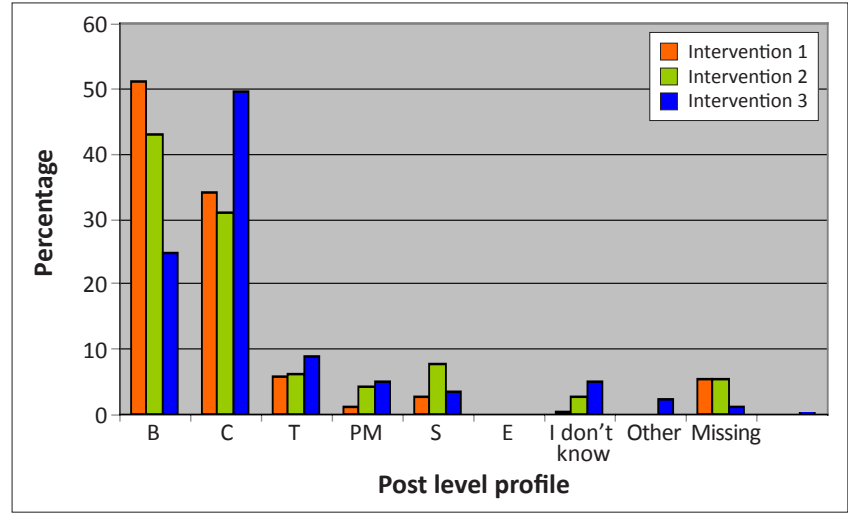

FIGURE 5: Post levels represented in the Absa Internal Choir Competition.

Most participants are employed at levels B (Entry Level) and C (Next Level). Between 2006 and 2008 there was an increase in participants from the higher post levels, namely $\mathrm{C}, \mathrm{T}$ (Junior Management) and PM (Middle Management).

Every year, amidst the disparity amongst its members, each aspiring choir embarked on a unique journey in the pursuit of becoming the winning Absa choir. Ultimately, each choir's achievement was that of their province and when a choir won, their entire province would share in the victory.

\section{The Absa Internal Choir Competition and teambuilding}

Businesses worldwide invest mammoth amounts in corporate teambuilding endeavours. Booysen envisioned the AICC as an investment ultimately strengthening 'the bigger Absa team'. In 2003 the Level Playing Fields Institute (Center for Survey Research, University of Connecticut) conducted an extensive survey to measure the opinions of employers and employees on issues in the workplace (HOW-FAIR 2003:28). The outcomes of the survey indicated that participants deemed 'being a team player' the most important factor in getting ahead in the workplace; more important than factors such as intelligence, leadership skills, performance, creativity, making money for the organisation or even contacts (whom you knew).
Authentic teams are not merely groups of people working together. Members of such groups function predominantly independently of the group, focusing on fulfilling personal goals and objectives rather than those of the team. Katzenbach and Smith (1993:111) explain: 'The essence of a team is shared commitment. Without it, groups perform as individuals; with it, they become a powerful unit of collective performance.' In the same way choirs are not merely groups of people singing together. The individual members need to develop into a body of singers producing a homogenous tone where no individual voices are discernable. Shared commitment and dedication to create a music experience greater than its members could ever achieve individually are vital to the success of every choir. This goal can only be achieved when each singer is continually attentive to the overall sound produced by the rest of the choir; and constantly adjusting his/her own sound to blend with the collective tone.

The literature on teamwork universally designates characteristics such as common goals, cooperation, unity, interdependency and willingness to sacrifice individual interest for the sake of group interest to successful teams (Van As 2009:55). The levels of cooperation, unity and interdependency involved in producing a musical choral performance should not be underestimated. Pioneering choral teacher, pedagogue and cofounder of the choral conducting department of the Moscow Conservatory, Pavel Chesnokov (2010), explains:

If we place ourselves in the center of a choir, we will notice a
great number of barely perceptible communications - tiny
threads that tightly link one section to another. We will notice
that these threads, which stretch from singer to singer and from
section to section, serve to adjust and regulate the sound ... We
also observe that each singer seeks to 'lean' on adjacent singers,
on his or her own section, and on all the other sections of the
choir, so that pitch and volume can be adjusted accurately ...
Each singer and each section must therefore endeavor to hear
the entire choral sonority, the ears of the singers (and, if you will,
the 'collective ears' of each section) thus informing them of their
exact position in the harmony. (p. 2) Exploring the concept of worldview as framework for creating a philosophical foundation for the theory of servant 
leadership, Wallace (2007:126) compares attributes of servant leadership (which include listening, empathy, healing and community) to eight Biblical worldview components. He indicates that listening is supported by six of these components, namely human dignity, personal responsibility, character, community, use of power, compassion and justice. The level of listening which evolves within a good choir will not be easily achieved in other contexts.

Developing the intricate listening and sensitive music skills as described by Chesnokov demands regular practice over an extended period of time. When an Absa employee became a member of an AICC choir, he or she committed to a challenging and at times cumbersome process. Over a period of six to seven months they had to attend choir practices of two to three hours every week. Taking a taxi or driving through peak time traffic after a full day's work, week after week, required endurance and discipline. Members of a choir often lived in different towns or regions (in the Northern Cape as far as $700 \mathrm{~km}$ apart) and had to travel for long distances (and many hours) to attend choir practices. The resolve to win the competition for their province was clearly a major driving force. AICC participants sacrificed significant amounts of personal time every week (usually evenings and weekends) and money (expenses such as travel, choir uniform and substitute caregivers for children) to attend practices.

Tuckman and Jensen (1977:419) identified five stages in team development. ${ }^{2}$ The researcher worked closely with 24 to 28 Absa choirs across South Africa from 2007 to 2010. It was interesting to observe the journey of the groups of Absa employees as they developed into choirs through the different stages leading up to adjournment, where members always expressed a sense of sadness and loss because the time with their 'choir family' had come to an end. AICC choir members democratically elected choir conductors, chose the material for the own choice item and designed the choir uniform. When forty choir members of dissimilar religions, races, cultures, beliefs, language and age groups have to debate the desirability or suitability of songs, dance movements and costume designs, conflict is unavoidable. However, the commitment to the choir's achievement in the final competition, and the members' love of singing always aided choirs to manoeuvre their team through storming to norming and finally to performing.

The dedication of Absa choir members to their choirs was astounding. One example of this dedication was a young female member of the Northern Cape choir hitch-hiking more than $700 \mathrm{~km}$ one Saturday night to attend a choir practice on Sunday morning. Her motivation was simply: 'I had to be here, I belong to this choir and I could not let them down.' It was evident that the sense of belonging to a community had provided this young woman with a sense of purpose

2. Forming: members - very polite - become acquainted with one another. Storming: interpersonal conflict begins; Norming: acceptable standards for team function: interpersolion are established, Pefforming. team now ready to focus and be productive; Adjournment: team disengages after successful completion of task. This can be a happy stage with congratulations on a job well done, or regrets for loss of friendships (Tuckman \& Jensen 1977:419). relating to the AICC. The sense of purpose and community generated through the AICC is echoed in the results of studies of the benefits of choral singing elsewhere. Clift and Hancox (2007:204) reported that the vast majority of the 1124 respondents in an extensive cross-national choral survey attributed an increased sense of coherence and community to choral singing, with $87 \%$ of respondents reporting social benefits. Findings of a survey amongst multi-cultural South African university choirs revealed that choir members experienced a genuine sense of community in their (multicultural) choirs (Barrett 2007:53).

The quantitative data of the survey of the value of the AICC for teambuilding in Absa are presented in the Figure 6.

Participants of all ages, positions in the bank, ethnic and language groups experienced choir participation as an excellent tool for teambuilding. The qualitative data revealed that the majority of participants considered teambuilding to be the single most important achievement of their choir. Comments included: 'Our teamwork has become very good'; 'I now have a sense of belonging'; 'There is a great sense of togetherness in our choir'; 'Unity - we are one'; 'We can overcome disagreements, we have become a team' and 'We have great cooperation in our choir'.

On a personal level, the majority of respondents viewed teambuilding as the greatest benefit of participating in the choir project. Comments included 'I have learnt to be a better team player'; 'Getting to know my colleagues with whom I spend a great deal of time'; 'I have learnt to cooperate with others'; 'Togetherness - a sense of belonging'; 'The people in my choir respect me' and 'I belong to a group where I feel appreciated'.

The significance of community, one of the eight broad JudeoChristian worldview components (Wallace 2007:126), and community building are promoted throughout the Old and New Testament of the Bible. The AICC, as platform for community building and experienced in a profoundly meaningful way by individual participants, shows how the ideal of community building can be concretised in a multicultural country with a divided past. On an organisational level, the social benefits and increased sense

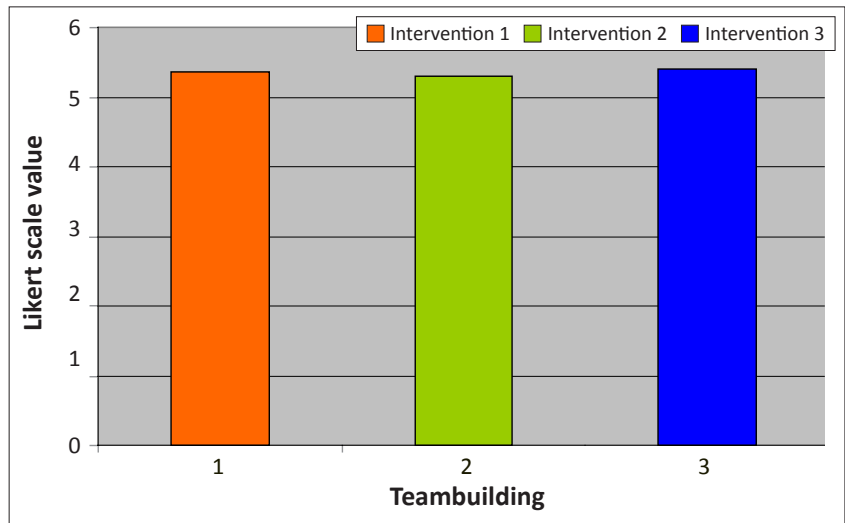

FIGURE 6: The value of the Absa Internal Choir Competition for teambuilding: participant views. 
of belonging to a bigger community are not directly related to the administrative or operational skills levels of the bank employees. However, principles of social capital indicate that it will ultimately be beneficial to the organisation.

\section{The Absa Internal Choir Competition and social capital}

Central to most definitions of social capital is the focus on social engagement, mutual reciprocity, trust and networks within communities. Relationships are considered to be significant, promoting the interconnectedness of people that underpins functioning communities with potential for productivity. The beneficial inclinations to do things for each other, known as 'norms of reciprocity', arise from these networks. Putnam (2000:411) notes that '... social capital is often a valuable by-product of cultural activities whose main purpose is merely aesthetic.' Collier (1998) expands: 'The most famous example of social capital is probably Putnam's amateur choirs ...' He explains three external effects of the choir:

- People who participate in the choir unconsciously learn to trust each other 'even though this is not the purpose of their interaction.' This causes a reduction in unethical behaviour which, in turn, reduces transaction cost.

- Potential choir members are influenced to develop enough trust to join (or form links with) the choir.

- Learning to trust fellow choir members enables participants to trust members of the broader society. Hence, choirs even benefit non-participants.

Figure 7 presents respondents' views on the influence of relationships developed in the choirs on cross-departmental transactions in the bank (factor 5).

The average mean of the three interventions for factor 5 ( $m=5.21)$ indicates that respondents found their choral participation beneficial to cross-departmental business in the bank. Putnam deems social capital a powerful resource as it facilitates cooperation. He regards the simple feat of associating together as the catalyst that spurs the social cooperation which makes democracy feasible: 'Good government in Italy is a by-product of singing-groups and soccer clubs ...' (Putnam 1993:176).

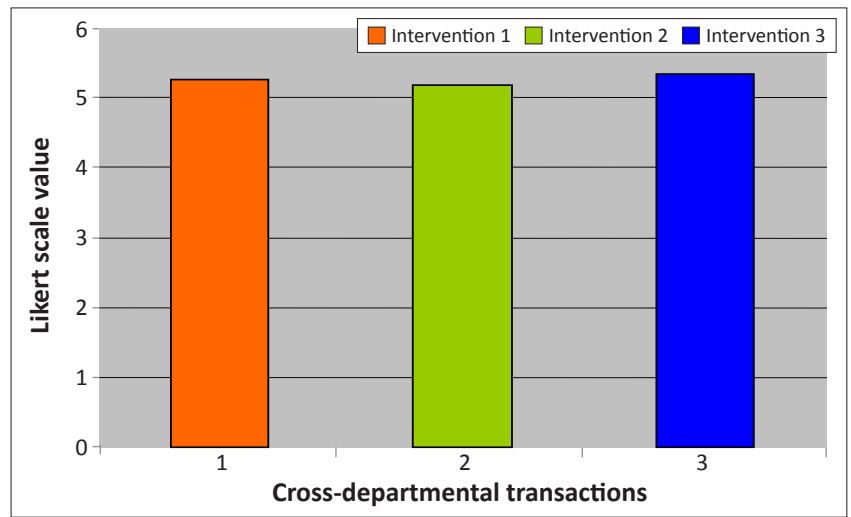

FIGURE 7: The value of choir participation for improved cross-departmental collaboration in the bank.

\section{The Absa Internal Choir Competition and transformation}

Transformation is not only a political imperative. Principles such as social justice, concern for the wellbeing of one's fellow human being, compassion for the poor, respect for and forgiveness of one another is fundamental to Christianity (Kulikovsky 2007:3-5). Whilst a South African understanding of transformation is often equated with equity, universal connotations of the term convey implications of a process of changing position or consciousness; a paradigm shift; a translation or conversion into an alternative form (Wolf 1980:1231; Collins dictionary and thesaurus of the English language 2011:1099; Oxford Paperback Thesaurus 2006:851). Transformation unavoidably implies change. Anderson and Ackerman Anderson (2001:39-48) distinguish between three types of organisational change, namely developmental ${ }^{3}$, transitional ${ }^{4}$ and transformational change, the latter being by far the most challenging. Transformational change engages on more personal levels of mindset, behaviour and culture: '... the people and the culture must change in order to be able to implement it. This requires new mindsets, behaviors and worldviews' (Anderson \& Ackerman Anderson 2001:40).

Apartheid encouraged minimal informal interaction between people of different races, depriving them of opportunities to gain insight into the spiritual, intellectual and/or emotional features of other social and cultural groups. As a result, the different ethnic groups' assumptions and judgments about one another were tainted, which in turn created superficial and often erroneous perceptions of fundamental truths about fellow South Africans. Unfortunately, this has not wholly changed (Webb 2002:15). After 12 years of democracy, Mkhize (2007) noted that:

special barriers remain entrenched, albeit on a psychological level. White incursions into 'black space' have not been matched by black movement into 'white space' ... This means that opportunities to learn about black communicative practices (or experiences) in black people's own terms and turf are limited, thus hampering meaningful transformation. (p. 3)

Language has been an important role player in apartheid intentions. It is common knowledge how the mandatory acquisition and usage of Afrikaans in the education of Black South Africans energised the struggle (Glaser 1998:320). However, not enough has been said about how meaningful communication between Black and White citizens has been inhibited by not including Black languages in White education curricula during apartheid. In a post-apartheid society, this inability to speak the languages of fellow countrymen becomes a barrier to gaining authentic insights about the 'other'. When somebody makes an effort to speak somebody else's language, it breaks down mistrust and builds a channel of communication that had not existed before.

Lomax (1968:17) observes that 'predictable and universal relationships have been established between the expressive

3.Developmental change focuses on improving current procedures such as existing skills, methods, team development and problem-solving efforts (Anderson \& Ackerman Anderson 2001:39-48)

4.Transitional change only impacts people at levels of skills and actions, and not at the more personal levels of mindset, behaviour and culture (Anderson \& Ackerman Anderson 2001:39-48). 
and communication processes, on the one hand, and social structure and culture pattern, on the other.' Choral singing is an expressive communication practice which embodies social and cultural aspects. The AICC encouraged choirs to use songs from all the cultures represented by their members. In preparation for the own choice section of the AICC, members of different cultural backgrounds learnt to sing one another's cultural songs. Members taught one another the words, the meanings of the songs, the contexts in which the songs were sung and the dance movements to the song. This created opportunities for shared communicative experiences. Building relationship with fellow members from other races facilitated disclosure of the self to others. When people of different cultural and language backgrounds sang together, the music served as insulator, a means of buffering the differences and raising awareness of their similarities.

After participating in an inter-university HIV-AIDS project in Lesotho where choral singing formed an integral part of the work, Deanna ${ }^{5}$, a post-graduate student from Empire College (State University of New York) commented in this regard:

Learning and performing music from other cultures allows the student to have an internal visceral experience with the languages and values of those cultures. This experience is unique because it internalizes this new cultural information before it can be analyzed or critiqued. Attempts at cultural understanding become more meaningful when this personal experience is considered, as the gap between self and other is bridged through the power of the song (Bergdorf pers. comm., 12 July 2008).

The AICC survey indicated that, through singing together in an Absa choir, respondents experienced increased respect for other South African cultures and races. Mutual respect permits disclosure of self to the other. Comments from the open-ended questions include: 'In our choir we have overcome racism'; 'I now want to learn a Black language' and 'We are not so different - we are one'. This is confirmed by the quantitative data.

Intervention 3, took place during the fourth AICC. At the time some employees had been singing together for four years. The particularly high score of 5.53 (out of a maximum 5.Name used with permission.

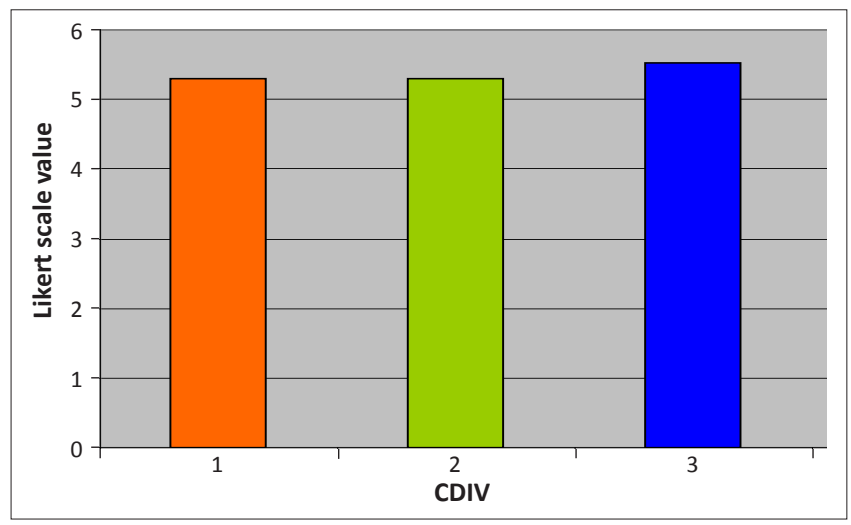

FIGURE 8: The value of choir participation for improving perceptions of and interaction with members of different races and cultural backgrounds. of 6) given by these participants indicates that prolonged exposure to others in the choir impacted the nurturing of respect for the other and his or her culture favourably. From a Christian perspective, respect can be seen as the interpersonal capacity to see and respond to another as a unique and valuable creation of God. According to GraufGrounds et al. (2008) respect visualises that God as Creator has purpose and meaning entrenched in the lives of each of God's creatures. Each person has worth and dignity that we can respond to and encourage within our interactions as well as within relationships (Grauf-Grounds et al. 2008). In this regard, it is clear that the AICC had a positive impact on the way in which participants valued and respected one another's worth. Jeannotte (2003) states:

If much of what we are and who we become is governed not only by shared meanings but also by how these shared meanings influence our relations with others, 'singing together' ... may hold benefits not only for oneself, but also for the people around us. Indeed, this singing may be a transformative experience and one of the key elements of a sustainable Community. (p. 35)

\section{Conclusion}

In his keynote address (recorded on a DVD supplied to the author in 2008) at the third AICC in 2007, Booysen stated:

When the idea of the choir was first floated, it was largely to give the employees of Absa the opportunity to have fun, socialise and get to know each other on a non-work related level. It has certainly achieved those three objectives, and so much more. The truth is: at the time we had no idea what was taking root. This initiative has transformed people's lives, produced lessons that, for all concerned, we could not have imagined. It has brought business benefits no training program could hope to imitate. (Van As 2009)

The results of the investigation on the effect of choir participation in the AICC on teambuilding, cross-departmental transactions and transformation (factor 3, factor 4 and factor 5) were overwhelmingly positive. Employees across South Africa clearly indicated that singing in Absa choirs had made it possible for them to build better relationships with fellow choir members of different races, cultures, language backgrounds and departments in the bank. The goodwill and trust generated by these new bonds had a positive influence on cross-departmental transactions in Absa.

Factors not discussed in this article investigated the level of enjoyment, increased pride in the Absa brand and the belief that employees were regarded as valued (factor 1 , factor 2 and factor 6). The outcomes of the investigation of these factors were overwhelmingly positive. In all three interventions the factor most highly rated by participating individuals was factor 1 (fun). Amidst the actual toil of practice and the rigor of social networking and participation, singing in an AICC choir was a source of joy. Bonhoeffer (1978) observes:

The more we sing, the more joy we will derive from it, but, above all, the more devotion and discipline and joy we put into our singing, the richer will be the blessing that will come to the whole life of the fellowship from singing together. (p. 61)

On the DVD (see Van As 2009) supplied to the author, Booysen (2006-2008) repeatedly commented on the 
wonderful spirit of the Absa choirs. Such a spirit is not attainable without the development of trusting and empathetic relationships amongst choir members (Snow \& Shelton 1995). Absa employees were not only singing for their supper, but also singing for the supper of future generations who can only benefit from the transformative experiences of this generation.

\section{Acknowledgements Competing interests}

The author declares that she has no financial or personal relationships which may have inappropriately influenced her in writing this article.

\section{References}

Anderson, D. \& Ackerman Anderson, L., 2001, Beyond change management: Advanced strategies for today's transformational leaders, Josey-Bass/Pfeifer, San Francisco.

Anderson, D. \& Ackerman Anderson, L., 2010, 'What is transformation, why is it so hard to manage?', in Being First, viewed 08 September 2012, from http://www. beingfirst.com/resources/pdf/SR_WhatlsTransformation_v3_101006.pdf

Ashkenas, R.N. \& Francis, S.C., 2000, 'Integration managers: Special leaders for special times', Harvard Business Review, November-December, 108-116.

Barrett, M., 2007, 'The value of choral singing in a multi-cultural South Africa', M.Mus dissertation, University of Pretoria.

Bonhoeffer, D., 1978, Life together: The classic exploration of Christian community, HarperOne, New York.

Chesnokov, P., 2010, The choir and how to direct it, Musica Russica, San Diego.

Clift, S. \& Hancox, G., 2007, 'The perceived benefits of singing: Findings from preliminary surveys with a university college choral society', Journal of the Roya Society for the Promotion of Health 21(4), 284-256.

Collier, P., 1998, Social capital and poverty, The World Bank, Washington, viewed 05 August 2011, from http://www.worldbank.org/socialdevelopment

Collins dictionary and thesaurus of the English language, 2011, Harper-Collins, Glasgow.

Glaser, C., 1998, "'We must infiltrate the tsotsis": School politics and youth gangs in Soweto, 1968-1976', Journal of Southern African Studies 24(2), 301-324.

Gordon-Brown, C., 2005, 'Making M\&As work', Wits Business School Journal, April, 72-79.

Grauf-Grounds, C., Edwards, S., MacDonald, D., Mui-Teng Queck, K. \& Tschermer Sellers, T., 2008, 'Developing graduate curricula faithful to professional training and a Christian worldview', Christian Higher Education 8(1), December.
HOW-FAIR, 2003, How opportunities in workplace and fairness affect intergroup relationships, University of Connecticut \& Level Playing Field Institute, San Francisco, viewed 28 August 2008, from Ipfi.org/docs/HOWFAIRReport.pdf

Jeannotte, M.S., 2003, 'Singing alone? The contribution of social capital to cohesion and sustainable communities', The International Journal of Cultural Policy 9(1), and sus.

Katzenbach, J.R. \& Smith, D.K., 1993, 'The wisdom of teams', Harvard Business Review $71(2), 111-120$

Kulikovsky, A.S., 2007, 'Justice and the Bible', paper presented at Summit Australia conference, Canberra, January 2007, viewed 08 March 2012, from http:// hermeneutics.kulikovskyonline.net/hermeneutics/JusticeAndBible.pdf

Lomax, A., 1968, Folk song style and culture, Transaction Publishers, New Brunswick.

Manuel, T., 2011, 'Parliamentary speech to launch the Diagnostic Report by Minister and Chairperson of the National Planning Commission, Minister Trevor A. Manuel', in South African Government Information, viewed 26 February 2012, from http:// www.info.gov.za/speech/DynamicAction?pageid=461\&sid=19030\&tid=34911

Matthews, R.E., 2011, 'Music style preferences of urban South African adolescents: A follow-up study including additional genres of Hip-Hop, House, Kwaito, Metal and Rhythm \& Blues', MA dissertation, University of Pretoria.

Mkhize, N., 2007, 'What is Transformation? Transformation as genuine dialogue', viewed n.d., from http://www.vryeafrikaan.co.za/site/lees.php?id=695

Oxford Paperback Thesaurus, 2006, Oxford University Press, Oxford.

Putnam, R.D., 1993, Making democracy work: Civic traditions in modern Italy, Princeton University Press, New Jersey.

Putnam, R.D., 2000, Bowling alone: The collapse and revival of American Community, Simon \& Schuster, New York.

Reddy, K., 2008, 'Transformation', in N. Shepherd \& S. Roberts (eds.), New South African Keywords, Jaconia Media, Auckland Park.

Smith, B., 1996, 'Choral music in South Africa', article written for the 1996 Salisbury Music Festival, England. (Obtained from the author).

Snow, S. \& Shelton, T., 1995, Singing with intention: nourishing spirit and imagination, viewed 09 September 2011, from http://web.me.com/slsnow/Site/Resources files/Singing\%20With\%20Intention\%20ACDA\%20NATL\%202011.pdf

Tuckman, B.W. \& Jensen, M.A.C., 1977, 'Stages of small-group development revisited', Group and Organization Management 2(4), 384-399.

Van As, A., 2009, 'Choir participation as tool for transformation and teambuilding in a corporate environment: A case study within Absa Bank', DMus dissertation, University of Pretoria.

Wallace, J.R., 2007, 'Servant leadership: A worldview perspective', International Journal of Leadership Studies 2(2), 114-132.

Webb, V.N., 2002, Language in South Africa. The contribution of language to the transformation, reconstruction and development of South Africa, John Benjamins, Amsterdam/New York.

Welch, G.F., 2005, 'Singing as communication', in D. Miell, R. MacDonald \& D. Hargreaves (eds.), Musical communication, pp. 239-257, Oxford University Press, London.

Wolf, H., 1980, Webster's new collegiate dictionary, G and C Merriam Company, Springfield. 